\title{
Wajah Indo dalam Iklan Tahun 1950an
}

\author{
Didit Widiatmoko Suwardikun \\ Desain Komunikasi Visual - Fakultas Industri Kreatif - Universitas Telkom. \\ Jalan Telekomunikasi - Terusan Buahbatu, Bandung 40257 \\ e-mail : widiatmokodw@gmail.com
}

\begin{abstract}
1950s society in Indonesia was marked by the changing social class, at the time of the Dutch East Indies, indigenous groups or "inlander" as the lowest grade. After the independence war a large number of indigenous people shifted into top class. That changes was used to advertise the consumer goods of international campanies. How was the figure of ideal model advertised at that time? Through visual analysis on consumer goods advertisement in newspapers published in the 1950s as well as an interview to the resource person, it was found that the visualization of women as a model, were wearing Indonesian dress, but the structure of the face and physical proportions were western type. Admiration for the beauty of western values is used as a tool to persuade the target audience, indigenous on new high social class, the women of Indonesia, especially in West Java which is famous for the light-skinned girl and a beautiful face.
\end{abstract}

Keywords : eurasian face, visual persuasion, advertisement.

\begin{abstract}
ABSTRAK
Dekade 1950an tatanan masyarakat di Indonesia ditandai dengan berubahnya kelas sosial, pada jaman Hindia Belanda, kelompok pribumi atau "inlander" sebagai kelas yang paling rendah, setelah perang kemerdekaan sejumlah besar orang pribumi bergeser menjadi kelas paling atas. Perubahan itu dimanfaatkan produsen untuk mengiklankan barang-barang konsumen produksi perusahaan internasional. Bagaimana figur ideal model iklan pada jaman itu? Melalui analisis visual pada iklan barang-barang konsumen di koran dan majalah yang diterbitkan pada tahun 1950an serta wawancara kepada narasumber, ditemukan bahwa visualisasi perempuan sebagai model iklan dengan cara berpakaian Indonesia, tapi struktur wajah dan proporsi tubuh bertipe Barat. Kekaguman terhadap nilai-nilai keindahan Barat digunakan sebagai alat untuk membujuk audiens target iklan, kelas sosial atas yang baru, para wanita Indonesia, khususnya di Jawa Barat yang terkenal dengan para gadis yang berkulit terang dan berwajah cantik.
\end{abstract}

Kata kunci: wajah indo, persuasi visual, iklan koran. 


\section{PENDAHULUAN}

Iklan dalam upaya persuasinya menampilkan sesuatu yang ideal, yang didambakan oleh khalayak yang menjadi sasaran iklan. Tampilan itu dapat berupa kejadian sehari-hari atau sekelumit kehidupan atau pergaulan yang dikaitkan dengan produk yang diiklankan. Untuk menarik perhatian pengamat dibuatlah iklan dengan ilustrasi figur atau model iklan. Penggambaran figur yang ditampilkan selalu disesuaikan dengan selera yang berlaku pada suatu jaman. Tahun-tahun awal kemerdekaan Indonesia adalah tahun 1950an, media iklan pada tahun tersebut adalah koran dan majalah, sedangkan radio belum digunakan sebagai media iklan, dan pada tahun 1950an belum ada televisi di Indonesia.

Koran yang cukup berpengaruh di Bandung pada jaman itu adalah koran Pikiran Rakjat. Iklan-iklan yang dimuat terdiri dari berbagai macam bentuk, mulai dari iklan baris hingga iklan bergambar $1 / 4$ halaman Koran. Yang diiklankan berbagai produk konsumen seperti jamu dan obatobatan, mainan anak, banyak iklan produk yang sasarannya adalah kaum wanita, seperti kosmetik, margarin dan minyak goreng. Dalam iklan-iklan ini gambaran figurnya adalah wanita tipe ideal pada jaman itu. Karena tampilan selalu berkaitan dengan sesuatu yang ideal dan mode yang sedang musim pada jaman itu, maka iklan adalah penggambaran ideal dari kondisi suatu jaman. Iklan selalu di sebar-luaskan secara berulang-ulang maka iklan juga turut membentuk gaya hidup suatu kelompok masyarakat. Tampilan iklan dan gaya hidup masyarakat saling mengisi.

Periklanan di Indonesia dimulai dari jaman Belanda, awalnya koran berbahasa Belanda mengiklankan produk konsumen untuk masyarakat Belanda di Indonesia.
Model iklan yang digunakan adalah wanita Belanda, sedangkan pribumi digambarkan sebagai pelengkap penderita. Pada Jaman Jepang model iklan berganti menjadi wanita Jepang, dan mulai muncul penggambaran wanita pribumi sebagai tokoh, bukan sebagai pelengkap (Suwardikun, 2009). Setelah Indonesia merdeka, tahun 1950 an awal masih banyak perusahaan milik Belanda yang beroperasi di Indonesia, seperti Unilever dan Borsumij, produkproduk mereka dipasarkan di Indonesia, disebar-luaskan melalui iklan koran. Beberapa biro iklan di kota Bandung yang masih dikelola oleh orang Belanda, diantaranya adalah milik Henk Ripassa di jalan Cikapundung dan biro iklan Phoenix di Jalan Raya Timur milik A. Stoltenkamp, beberapa desainer iklannya pun masih orang Belanda, karena pada waktu itu masih sedikit orang pribumi yang memiliki keterampilan memadai untuk membuat desain iklan. Ciri budaya perkotaan pada waktu itu adalah budaya Mestizo atau Indo, dari beberapa sumber disebutkan bahwa kota Bandung yang dikelilingi oleh perkebunan milik orangorang Belanda, maka banyak keturunan Indo Belanda. Ilustrasi iklan yang menarik sering menggambarkan wanita sebagai figur iklan. Kota Bandung yang dikenal sebagai kota kembang dengan Mojang Priangan yang secara tipikal cantik menarik, ramah dan selalu ikut mode, maka sebagai pertanyaan penelitian adalah bagaimana penggambaran figur wanita dalam iklan-iklan produk konsumen di koran Pikiran Rakyat tahun 1950an?

\section{METODE}

Fokus penelitian pada iklan-iklan koran produk konsumen tahun 1950an, dengan kriteria iklan berilustrasi yang mengambarkan wanita, berukuran sekitar 
$1 / 4$ halaman koran atau $19 \times 25 \mathrm{~cm}$. Sampel dari koran Pikiran Rakjat yang terbit di Bandung dari bulan Maret hingga bulan Oktober 1951 terkumpul 26 iklan berilustrasi dengan ukuran $1 / 4$ halaman koran, dari jumlah itu 20 diantaranya menampilkan figur wanita. Yang dikaji pada iklan dalam penelitian ini adalah visualisasi iklan, pengaruh lingkungan, wawasan, konsep diri, dan persuasi. Pendekatan dengan kajian estetik atau kajian teks pada visualisasi, dilakukan melalui analisis visual untuk mendapatkan makna dan ideologi yang terkandung didalamnya. Untuk memahami pengaruh lingkungan yang terjadi, sampel iklan dibandingkan juga dengan penggambaran oleh pelukis terkenal pada jaman itu dan membandingkan penggambaran figur dalam iklan dengan isi syair lagu yang terkenal saat itu "Mojang Priangan". Untuk mendapatkan rekonstruksi tentang kehidupan sosial masyarakat kota Bandung pada dekade tahun 1950an dilakukan wawancara mendalam kepada beberapa narasumber yang hidup pada jaman tersebut. Studi pustaka pada buku-buku dan tulisan yang berkaitan dengan kondisi sosial dan budaya yang berlaku pada masyarakat Bandung pada tahun 1950an. Wawasan atau insight terbentuk dari pengaruh lingkungan sehingga membentuk konsep diri menjadi pencerminan ideal, digunakan untuk persuasi bagi khalayak sasaran.

\section{HASIL DAN PEMBAHASAN}

Hasil pengamatan terhadap visualisasi dari 20 iklan, 18 iklan menampilkan wanita berpakaian kain-kebaya dan rambut di sanggul, wanita digambarkan dengan proporsi badan orang Eropa dengan ukuran leher dan torso yang panjang, juga terlihat pada ukuran lengan, siku dan jari tangan, demikian pula bentuk wajah yang lonjong. Hal ini pertama terwakili pada iklan minyak goreng Filma (lihat gambar 01).

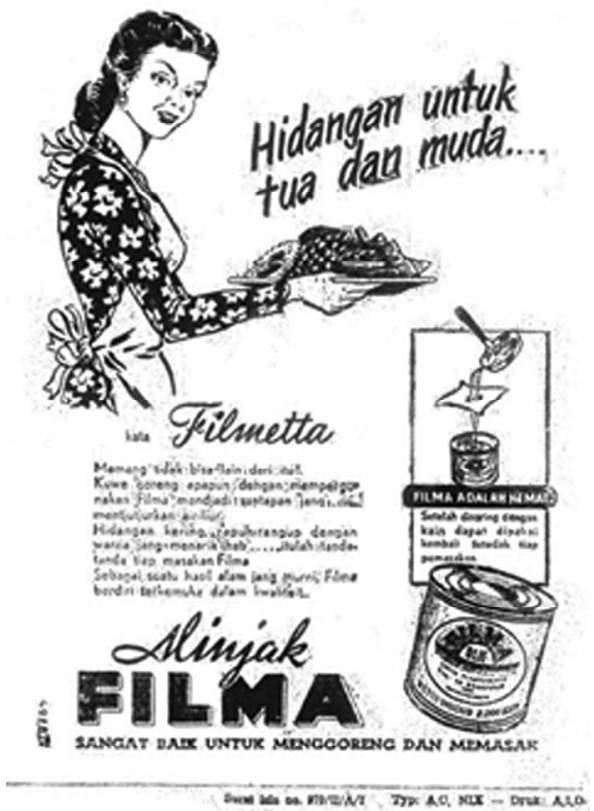

Gambar 01:

Iklan Minyak Goreng Filma

Sumber : Koran Pikiran Rakjat, 29 Januari 1951

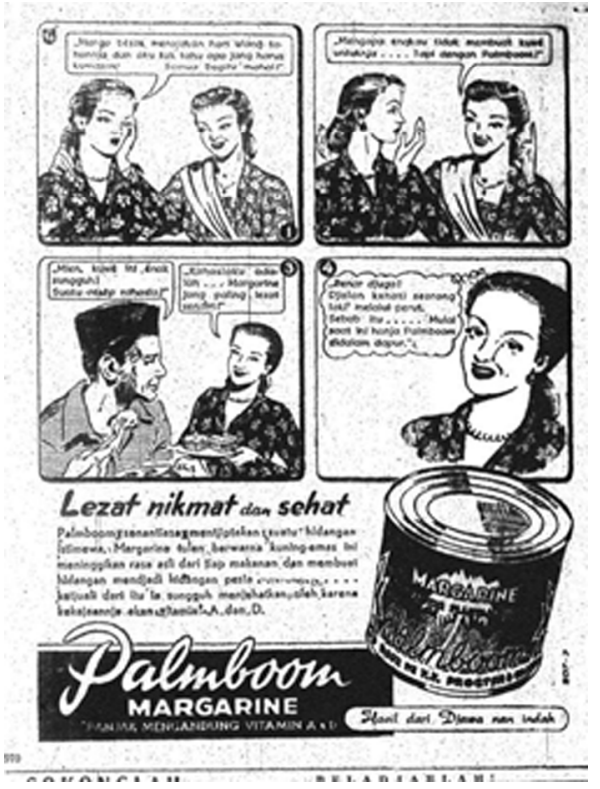

Gambar 02:

Iklan Minyak Goreng Filma

Sumber : Koran Pikiran Rakjat, 16 Maret 1951 
Wanita dalam iklan ini terlihat menjadi pribumi Indonesia karena digambarkan memakai baju kebaya, dan tata rambut disisir dan disanggul. Bentuk mata, alis dan bibir seperti penggambaran bintang film barat. Leher terlihat panjang dan juga wajah yang lonjong, bentuk alis dan bibir tipikal aktris Hollywood. Figur iklan digambarkan memakai celemek berpita, untuk memberi kesan wanita moderen, karena yang memasak sambil berdiri dan menggunakan celemek adalah wanita barat. Sesungguhnya cara memasak tradisional Indonesia dilakukan sambil berjongkok di depan tungku berbahan bakar kayu, pada dapur yang penuh asap sehingga tidak perlu menggunakan celemek.

Iklan kedua adalah iklan margarin Palmboom dengan tataletak gaya komikstrip, menggambarkan dua wanita sedang berdialog, dan seorang pria berkopiah. Kedua wanita memakai pakaian kebaya, yang seorang memakai selendang dan rambut ikal disanggul. Proporsi tubuh dan anggota badan, terutama leher kedua wanita ini terlihat panjang, demikian pula bentuk wajahnya. Riasan bibir yang digambarkan memakai pemerah bibir seperti gaya riasan bibir bintang film Hollywood. Pria dengan sikap tubuh dan wajah dengan proporsi barat, digambarkan memakai kopiah (gambar 02), karena kopiah dalam hal ini sebagai simbol nasionalis dan agama Islam.

Penggambaran gaya hidup secara umum, wanita Indonesia digambarkan menjadi ratu rumah tangga, mengerjakan pekerjaan-pekerjaan rumah tangga, seperti memasak, mengurus suami dan anak. Pencerminan kegiatan seperti ini terdapat hampir pada semua iklan yang dijadikan sampel. Namun ada yang menampilkan gaya hidup wanita moderen, yaitu pada iklan Palmboom (lihat gambar 03). Dua orang wanita menaiki mobil sport convertible (atap dapat dibuka), bukan mobil sedan biasa.
Salah seorang memakai kain selendang segitiga atau "driehoek" yang diikatkan di kepala, untuk menutupi rambut seperti yang dilakukan wanita barat bila berpiknik. Pada tahun 1950 wanita pribumi yang dapat menyetir mobil masih sangat sedikit, demikian pula jumlah mobil di kota Bandung. Penggambaran ini mencerminkan strata atas, karena strata rakyat biasa tidak mungkin memiliki mobil seperti ini. Setelah sampai di rumah mereka masih meneruskan pembicaraan dengan menggunakan pesawat telepon, benda ini pun pada jaman itu masih terbatas jumlahnya, hanya kantor dan rumah golongan atas yang memilikinya. Pemikiran seperti ini merupakan pemikiran yang maju karena pemikiran yang ada pada saat itu kebanyakan wanita masih dianggap berada di dalam rumah, mengurus rumah tangga, sedangkan kedua wanita ini keluar rumah menyetir mobil sendiri, tidak dibantu oleh pria. Hal ini mencerminkan kebebasan dan kemandirian bagi wanita. Persuasi visual ditampilkan melalui gambar yang dapat memancing berbagai makna, sedangkan teks verbal berfungsi sebagai jangkar atau anchoring terhadap gambar yang ditampilkan.

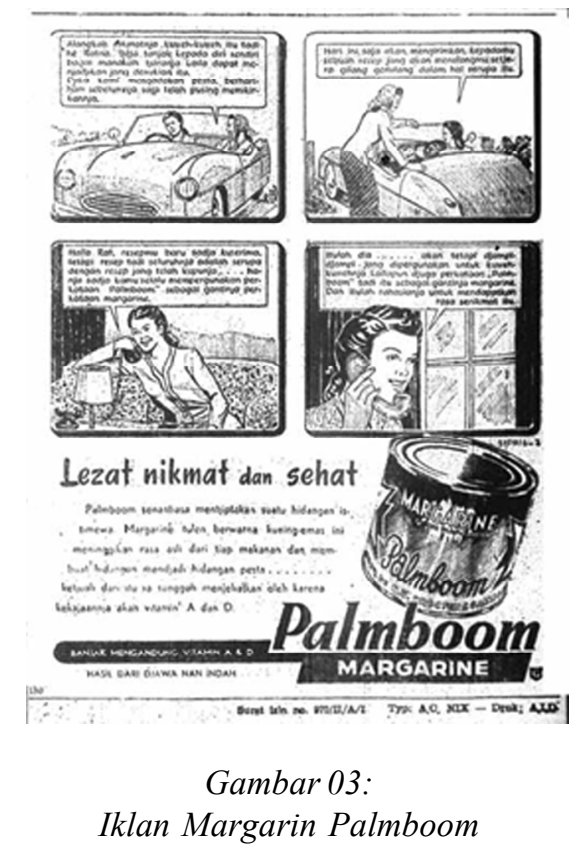

Sumber : Koran Pikiran Rakjat, 11 Januari 1951 
Dalam iklan palmboom versi mobil sport ini, untuk mengaitkan gambar dengan produk maka teks dibuat seolah tentang persoalan bagaimana membuat kue yang enak. Secara visual perilaku yang ditampilkan dalam iklan ini lebih menampilkan gaya hidup dibandingkan dengan kaitannya dengan penggunaan produk yang diiklankan.

Wanita yang ditampilkan dalam iklaniklan ini menggunakan pakaian dan dandanan khas Indonesia, yaitu memakai kain dan baju kebaya. Hampir semua iklan di Indonesia menampilkan wanita dengan gaya seperti ini, sehingga ciri khas wanita Indonesia adalah memakai kain dan kebaya dan pasangan pakaian model ini adalah cara menata rambut yang disisir kebelakang dan di lipat atau digulung yang disebut sanggul. Berbagai macam bentuk sanggul ini, mulai dari bentuk yang rumit seperti sanggul model Jawa tengah hingga sanggul yang praktis. Wanita-wanita pada iklan-iklan diatas rambut mereka digambarkan sedikit bergelombang disisir dengan belahan dan berjambul didepannya, walaupun dibelakang diikat berbentuk sanggul, tetapi terlihat lebih praktis dan sederhana.

Dari penggambaran wanita pada iklan diatas coba selanjutnya dilihat pada lukisan Basuki Abdullah yang berjudul "Gadis Sunda." (gambar 03)

Seorang gadis sedang duduk diatas tilam atau kasur tipis, disebuah ruangan berdinding anyaman bambu. Sang gadis memakai kebaya berwarna kuning dengan kain yang ujungnya dilipat-lipat atau "dilamban". Tangan kiri memegang selop bertumit tinggi yang dilepas dari kaki kanannya seperti habis melakukan perjalanan jauh. Wajahnya melihat kebawah, alis tebal dan rapi, bentuk wajah, hidung, mata dan mulut digambarkan dengan ukuran dan ukiran yang menawan.

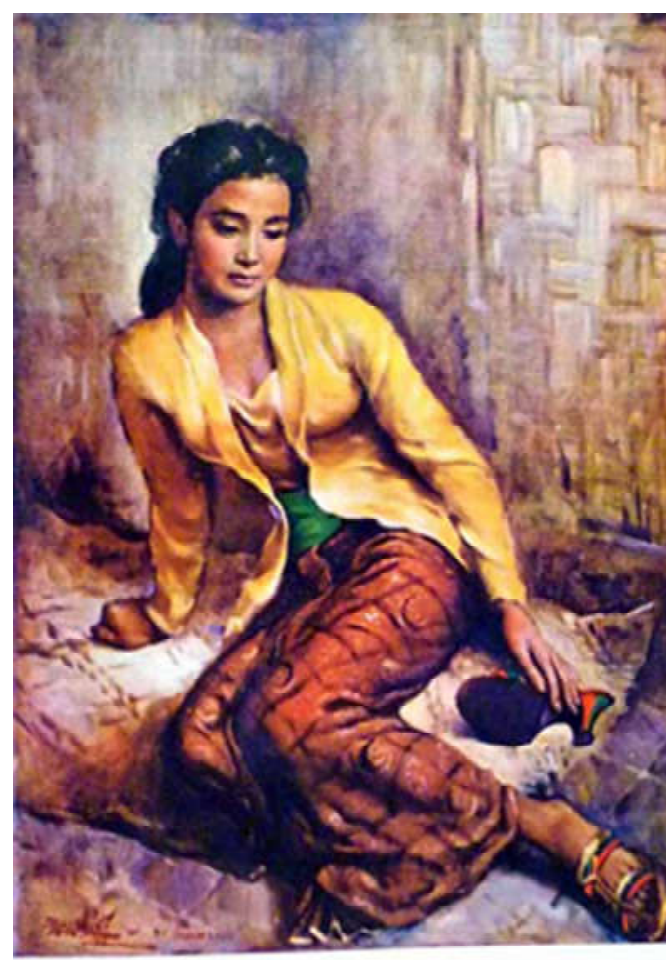

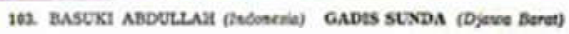

Gambar 04:

Lukisan Basuki Abdullah "Gadis Sunda" Sumber : Buku Lukisan-lukisan

Koleksi Sukarno, 1956

Penggambaran rambut, hitam, tebal, bergelombang dan bentuk sanggul sama dengan model rambut para wanita dalam iklan-iklan Filma dan Palmboom.

Proporsi badan langsing dan berkaki panjang, sehingga apabila dicocokkan dengan lagu "Mojang Priangan" yang pada jaman dahulu dilantunkan oleh Upit Sarimanah, dari cuplikan syairnya apabila diterjemahkan antara lain menyebutkan : "Jalannya melenggang; Bentuk tubuh tiada cela; Memakai kain dengan lipatan ganda di ujungnya; Memakai baju kebaya sehingga menambahnya bercahaya, berdandan sederhana; Memakai kain membalut kaki yang tinggi semampai, membuat yang melihatnya menjadi semakin terbuai; Gadis yang cantik, jika dipandang membuat hati rindu." Hasil analisis visual terhadap iklan produk konsumen tahun 1950an, pengamatan 
terhadap lukisan Basuki Abdullah yang dibuat pada tahun 1951 serta lirik lagu "Mojang Priangan" yang di buat pada era yang sama, dinyanyikan oleh ibu Upit Sarimanah, saling mengisi mengarah kepada suatu pengambaran yang ideal tentang wanita Indonesia.

Penggambaran wanita Indonesia dengan proporsi tubuh, bibir, alis dan mata model barat namun ukuran wajah dan hidung kecil, memakai pakaian ciri khas Indonesia, yaitu kain dan kebaya. Perilaku barat, penggambaran gaya hidup kelas tinggi dan kebebasan bagi dua orang wanita yang digambarkan dengan ciri Indonesia, karena berpakaian kain kebaya, dengan gaya rambut dan asesoris yang sedang musim pada saat itu.

Pengaruh lingkungan terjadinya iklan. Pada jaman penjajahan Hindia Belanda, pribumi menjadi kasta paling rendah, kecuali segelintir pribumi yang mendapat pangkat atau kedudukan lebih tinggi, adalah mereka yang membantu Belanda menarik pajak dari rakyat ("pangreh pradja") atau menjadi kaki-tangan Belanda. Segala sesuatu yang ideal adalah Belanda, sehingga menjadi Belanda termasuk sebagai cita-cita pribumi agar dapat hidup layak. Apakah itu bersekolah Belanda, berbahasa Belanda, berpakaian dan berdandan model Belanda. Keinginan membelanda itu terbentuk karena penjajahan beratus tahun yang dalam teori Carl Gustav Jung disebut "ketidaksadaran kolektif" (Jung, dalam Hall dan Lindzey, 1993:184), adalah sisa-sisa psikik perkembangan evolusi manusia, sisa yang menumpuk sebagai akibat dari pengalaman-pengalaman yang berulang selama banyak generasi. Ingatan-ingatan laten atau potensial ini tergantung pada struktur-struktur dan jejak-jejak inheren yang sudah tertanam dalam otak sebagai hasil pengalaman kumulatif. Ketidak- sadaran kolektif merupakan fondasi ras yang diwariskan dalam keseluruhan struktur kepribadian. Alasan lain dari keinginan untuk menjadi Belanda ini dikemukakan oleh Wertheim sebagai upaya pembaratan untuk mengejar ketinggalan budaya banyak dilakukan terutama oleh generasi muda baik pria maupun wanita, masuknya ideologi rasionalisme, individualisme dan liberalisme. Namun menurut Wertheim (1956), tidak semua budaya barat ini ditelan oleh generasi muda Indonesia. Mereka mengalami apa yang disebut sebagai "pencuplikan budaya" yang kemudian disesuaikan atau diadopsi seolah menjadi budaya lokal. Budaya yang direpresentasikan oleh kelompok orang-orang Eropa di abad 19 di Indonesia tidak murni peradaban barat, melainkan campuran, semacam budaya "mestizo" atau budaya Indo. Pola perilaku dipungut oleh orang-orang Indonesia dari orang-orang Eropa, dengan demikian juga menjadikan banyak ciri khas budaya indo. Ketika bertambahnya kelompok pendatang baru Eropa mengembangkan cara hidup baru, yang lebih mengarah kepada duplikat pola kehidupan masyarakat Belanda, maka budaya indo mengalami kemajuan diantara kelompok pribumi.

Upaya untuk meniru barat tidak terbatas pada kelas atas dari masyarakat Indonesia. Selama masa penjajahan Hindia Belanda bertambahnya jumlah orang-orang Eropa, yang muncul tidak hanya di kotakota besar, juga di kota-kota kecil, munculnya gambar-gambar iklan barat, dan kemudian bioskop yang menciptakan model-model budaya yang terbukti lebih atraktif, khususnya kepada kalangan muda. Pakaian bergaya Eropa, saku dilengkapi dengan fulpen, kacamata berbingkai tanduk dan gigi dilapis emas menjadi simbol perbedaan status sosial, sebagaimana juga 
olahraga, terutama tennis sebagai sebuah hiburan favorit dari kalangan muda Indonesia. Wanita pun tidak mau ketinggalan dalam upaya pembaratan. Sebagaimana pendidikan membawa budaya barat kepada banyak gadis-gadis, gaya hidup, pemikiran tentang perkawinan dan moralitas ala barat menyusup semakin dalam pada masyarakat Indonesia. Meskipun kehidupan sosial tidak dapat dikategorikan secara jelas, namun dapat ditunjukkan beberapa ekspresi kebudayaan massa yang bersifat kolektif, dalam artian bahwa mereka berangkat dari pola-pola tradisional menuju kearah peralihan yang berlangsung cepat dan tidak stabil, seperti halnya mode pakaian terkini menjadi cepat berlalu. Ekspresi perilaku pada tingkat kolektif adalah iklan-iklan, bacaan-bacaan populer, dan film, ekspresi ini tumbuh dari interaksi diantara anggota-anggota kelompok yang bergerak diluar pola-pola tradisional, diluar keteraturan yang merupakan perilaku umum.

Setelah Indonesia merdeka tangal 17 Agustus 1945, Jepang kalah perang dan menyerah kepada sekutu, kemudian Jepang meninggalkan Indonesia. menurut Wertheim (1956), walaupun sebentar, pendudukan Jepang tahun 1943 - 1945 menjadikan berbaliknya semua nilai. Kulit putih dan penggunaan bahasa Belanda yang telah begitu lama menjadi simbol dari superioritas orang Eropa telah digugurkan. Banyak orang-orang blasteran Indo-Eropa yang sebelumnya ingin menyembunyikan asal usulnya, karena malu dengan darah separuh pribumi Indonesia, setelah perang kemerdekaan berusaha keras untuk mendeklarasikan bahwa mereka adalah peranakan, anak-anak dari tanah air Indonesia. Sedangkan orang-orang pribumi Indonesia yang telah begitu lama menjadi strata yang terendah, meningkat menjadi lebih tinggi daripada Indo-Eropa dan Tionghoa Indonesia (Wertheim, 1956: 133). Dari pendapat ini disimpulkan bahwa setelah kemerdekaan budaya indo semakin dijadikan mode di perkotaan, yang diadopsi oleh masyarakat pribumi.

Budaya Indo sebagai ciri khas budaya perkotaan yang menjembatani budaya Eropa dengan budaya lokal pribumi. Yang disebut golongan peranakan atau IndoEropa adalah orang-orang keturunan, hasil perkawinan campuran dari seorang ayah bangsa Eropa (umumnya Belanda) dengan ibu wanita pribumi. Pada jaman awal kemerdekaan di wilayah Priangan, khususnya di Kota Bandung, banyak ditemui orang-orang dari golongan Indo Eropa. Menurut Haryoto Kunto (1986), proses pembauran antara bangsa Eropa dengan orang-orang pribumi di wilayah Priangan telah berlangsung beberapa abad, terutama menyangkut asimilasi antara orang Belanda yang hidup sebagai Preangerplanters (pengusaha perkebunan di Priangan) dengan para wanita pribumi di perkebunanpegunungan. Agaknya salah satu faktor yang membuat menarik wajah Bandung tempo doeleoe, adalah tampang "Indo Eropa" yang mewarnai kehidupan masyarakat kota. Memang demikianlah, wajah "Bandung Baheula" memiliki aksen dan citarasa yang kebarat-baratan. Justru disitulah sebenarnya letak keistimewaan kota Bandung.

Kegiatan yang paling populer bagi remaja dan dewasa muda pada waktu itu adalah menonton film di bioskop. Film-film yang diputar di bioskop-umumnya film Amerika, dengan komentar (subtitle) selain diterjemahkan dalam bahasa Indonesia, juga dalam bahasa Belanda. Bioskop Pada 1950 an secara umum merupakan hiburan dan rekreasi remaja di kota besar.

Menurut Katam dan Abadi (2006), di kota Bandung sekitar pusat kota atau alun- 
alun kota terdapat 5 gedung bioskop. Elita, Varia, Oriental dan Radio City yang berubah menjadi Dian dan Majestic yang terletak di belakang gedung Asia-Afrika. Lingkaran yang sedikit lebih jauh terdapat bioskop Capitol, Texas dan Garuda di jalan Raya Barat, bioskop Silihwangi di jalan Astana Anyar, bioskop Braga Sky di jalan Suniaraja, bioskop Kapitan di jalan Karapitan.

Ketika orang-orang pergi untuk menonton film ke bioskop, mereka pergi dengan tujuan untuk melepaskan diri dari kehidupan sehari-hari yang membosankan, walaupun hanya untuk sesaat, mereka memiliki mimpi bersama. Menonton filem adalah mengisi pikiran dengan kehidupan yang ada dalam film, karena kondisi menonton di bioskop dalam suasana gelap, sumber cahaya hanya pada layar, sehingga perhatian penonton semua terfokus pada layar. Kondisi seperti ini memungkinkan bagi penonton untuk "feeling into" pada cerita film yang ditonton, jika sedih penonton ikut menangis, jika adegan kemenangan, penonton ikut berteriak dan bertepuk tangan, seolah penonton ikut berperan dalam adegan-adegan film tersebut. Aktor dan aktris dalam film menjadi tokoh yang dikagumi, ditiru cara berdandan, cara menyisir rambut dan membentuk pemerah bibir. Menonton film-film Amerika produksi Holywood yang sejak lama telah merajai dunia, dengan kehidupan para bintangnya banyak dimuat di koran atau majalah hiburan terbitan dalam dan luar negeri yang beredar di kotakota besar di Indonesia. Koran dan majalah tersebut memuat iklan-iklan yang terpengaruhi adegan-adegan dan pose dari dari bintang film barat.

Kekaguman terhadap kecantikan dengan kriteria barat dimanfaatkan oleh pengiklan untuk mengambarkan figur model iklan pada saat itu. Walaupun teknologi fotografi belum banyak digunakan oleh periklanan, namun penggambaran secara manual dari figur model iklan dapat mereperesentasikan wanita tipe barat. Tidak banyak iklan berwarna muncul di media cetak, iklan berwarna di majalah hanya tersedia untuk halaman sampul saja. Kalaupun ada, tidak digunakan untuk memperoleh tambahan dampak atau me-ningkatkan perhatian pembaca, tetapi lebih Sering digunakan sekedar unsur dekorasi, untuk memeriahkan atau merayakan suatu peristiwa penting. Pengenaan tarif iklan sudah menggunakan standar milimeter-kolom. Penulisan naskah, iklaniklan produk konsumen tampak mengalami kemandegan. Sebagian besar rancangan produk iklan dalam negeri bertemakan "anjuran memakai" yang monoton. Kata-kata "pakailah selalu" senantiasa digunakan dalam setiap teks iklan. Menurut Setiyono (2004), secara visual pengaruh "Hollandsch denken en Hollandschinzicht" (berpikir dan berwawasan ala Belanda) juga masih dominan.

Adegan dalam iklan merupakan sesuatu yang direncanakan karena tujuan utama untuk penjualan barang yang diiklankan. Apabila terjadi dialog visual antara sosok manusia atau sosok yang digambarkan dalam iklan dan pemirsa, maka sosok tersebut dapat berfungsi sebagai pencerminan diri dari pemirsa. Dari pendapat Jaques Lacan (1977), teori cermin aku melihat aku, dalam hal ini seolah pengamat melihat cermin yang merefleksikan dirinya. Sehingga apa yang dipakai dan diperagakan oleh model iklan adalah juga untuk dipakai oleh pengamat. Iklan dapat juga menggambarkan sesuatu yang ideal bagi kehidupan, sosok yang ditampilkan dengan nilai-nilai ideal, untuk memancing cita-cita pengamat menjadi sesuatu yang ideal. Apa yang terbentuk oleh persepsi dalam pikiran 
pengamat menjadi konsep diri atau citra diri, adalah cara seseorang melihat diri sendiri, apakah cerminan dari dirinya sendiri seperti apa adanya, atau diri yang menjadi ideal karena pengaruh wawasan diri menjadi ideal.

Iklan merepresentasikan suatu bentuk perilaku kolektif, dimana seseorang dibujuk untuk membeli komoditi yang membuat hidupnya lebih menyenangkan atau nyaman, sehingga seseorang akan dapat menunjukkan kepada para tetangganya bahwa dia sukses secara ekonomi, dan membuktikan kepada dirinya dan orang lain bahwa dia selalu memakai mode terbaru sehingga ia dianggap menjadi orang yang terdepan dalam kemajuan. Menurut Merril dan Eldredge (1956), bersamaan dengan ekspresi-ekspresi perilaku kolektif lainnya, iklan menciptakan dorongan untuk keluar dari pola-pola yang telah berlaku lama. Perancang iklan atau creative director mengukur wawasan atau perasaan terpendam (insight) masyarakat, dan di sisi lain untuk merangsang aktivitas yang jelas sebagai akibat dari dorongan ini. Hasil akhir dari sebuah iklan adalah penerimaan gaya hidup yang baru oleh banyak individu; dimana seseorang bertindak sebagai individu dan bukan sebagai bagian dari gerakan sosial. Dorongan-dorongan atas keseragaman dan individualitas keduanya sangat penting dalam periklanan, sebagaimana dalam mode busana, dan perilaku ini merupakan bentuk khusus dari perilaku kolektif (Merril dan Eldredge, 1956: 308). Dalam mode busana, seseorang akan berusaha mengikuti mode yang berlaku, namun enggan bila di katakan bahwa yang dikenakannya adalah baju kodian.

Pada tahun 1950an menjadi ideal adalah masih meniru Belanda tetapi tidak seratus persen, karena masih diperlukan unsur identitas pribumi sebagai euforia kemerdekaan. Para pribumi yang sekarang menduduki kelas sosial paling atas masih mempunyai pandangan seperti itu. Bahkan sampai sekarangpun wajah indo masih menjadi favorit dikalangan selebritis. Kekaguman terhadap segala sesuatu yang berbau asing terutama Eropa, seperti mode busana, kosmetik, parfum dan barang perhiasan.

Visualisasi, bentuk wajah dan proporsi tubuh yang panjang dan wajah tipe Barat dipadukan dengan tata rambut yang disanggul dan pakaian kain kebaya. Celemek sebagai simbol cara Barat yaitu memasak dengan posisi berdiri, sedangkan orang pribumi mempunyai kebiasaan memasak dengan berjongkok.

Pengaruh lingkungan, perusahaanperusahaan multinasional yang pada waktu perang kemerdekaan meninggalkan Indonesia, mulai kembali lagi memasarkan produk-produknya dan memasang iklan untuk pemirsa pribumi, yang setelah perang kemerdekaan menjadi kelompok menengah atas. Pada tahun 1950an kainkebaya dan rambut panjang disanggul sebagai pakaian nasional, karakter pribumi, golongan menengah atas. Iklan apabila menggunakan model orang Barat maka dianggap barangnya berkualitas, masyarakat Indonesia masih menyukai tokoh berkarakter Barat, karakter dari bangsa yang sedang dalam masa "pancaroba", menyukai tokoh-tokoh idola yang berwajah Indo.

Wawasan, pengiklan menganggap pemirsa menginginkan dalam mengelola rumah tangga praktis dan modern seperti wanita Barat, tetapi masih memiliki karakter pribumi.

Konsep diri, menggunakan visualisasi sosok dengan karakter Barat ditambah dengan tanda-tanda yang sama dengan 
pemirsa sasaran, membentuk gambaran ideal bagi diri pemirsa, membentuk konsep diri aku - ideal.

Persuasi, menggunakan pendekatan adaptasi budaya, memakai cara berpakaian wanita pribumi pada sosok wanita bertipe Barat. Iklan ditujukan untuk kalangan wanita dewasa pribumi, menawarkan sesuatu yang hemat, lebih mudah dan praktis dengan menggunakan persuasi visual, penggambaran ideal sosok wanita dengan proporsi tubuh dan wajah Barat dibuat menyerupai atau mendekati karakter pemirsa, berpakaian seperti wanita pribumi. Kebaruan, modernitas dan kepraktisan digambarkan wanita ibu rumah-tangga mengenakan celemek, serta suasana sarapan gaya Barat, wanita tipe Barat dengan identitas Indonesia.

\section{SIMPULAN}

Nilai-nilai dan kebiasaan dari tempat produsen diadaptasikan dengan karakter stereotip khalayak sasaran seperti pakaian kebaya, rambut disanggul menjadi menjadi alat persuasi bagi khalayak sasaran, pribumi kelas menengah.

Persuasi, menggunakan pendekatan adaptasi budaya, memakai cara berpakaian wanita pribumi pada sosok wanita bertipe Barat.

Produk produk yang diiklankan berasal dari perusahaan multinasional yang memasarkan produknya untuk kalangan menengah atas Indonesia, yang pada tahun 1950-an setelah kemerdekaan Indonesia, kaum pribumi menjadi naik strata sosialnya.

Orang-orang Indonesia masih lebih yakin jika sosok yang digunakan dalam iklan adalah tokoh idola Barat karena mengasosiasikan barang berkualitas tinggi. Figur yang ideal adalah figur yang ditampilkan dalam iklan, sehingga khalayak sasaran yang secara tidak sadar terpersuasi akan meniru atau mengikuti nilai-nilai yang ditampilkan. Penggambaran seperti ini merupakan gambaran ideal bagi suatu masyarakat, maka secara tidak sadar akan terpengaruh dalam kehidupannya. Gaya berpakaian, gaya tata rambut bahkan gaya hidup pun akan merembes pada kehidupan khalayak sasaran.

Nilai kecantikan yang ditampilkan adalah kecantikan ideal barat yang dikemas atau diadaptasikan dengan kondisi lokal. Kekaguman terhadap sesuatu yang berbau barat sudah dibuat mengakar sejak jaman penjajahan Belanda, dibentuk dari ketidaksadaran kolektif dan pencuplikan budaya, membentuk suatu stereotip kecantikan ideal yang dapat digunakan untuk persuasi visual dalam iklan.

Ucapan Terimakasih :

- Komar Hanafie, Praktisi periklanan tahun 1970an di Bandung.

- Haryadi Suadi, Ilustrator, Pengamat Ilustrasi, Pengajar FSRD ITB

- Ny. Retna D. Abdurahman, Ketua Yayasan Taman Lalulintas, Bandung.

- Ny. Rumini Tamim - Mohamad, Ibu rumahtangga, Jl Bukit Dago Utara, Bandung.

- Perpustakaan Nasional, Jakarta : File Koran Pikiran Rakjat, 11 Januari 1951, 29 Januari 1951, 16 Maret 1951.

- Youtube.com : Lagu “Mojang Priangan", Upit Sarimanah.

\section{Daftar Pustaka}

Bedjo Riyanto

2000 Iklan Koran dan Perubahan Masyarakat Di Jawa Masa Kolonial (1870-1915), Yogyakarta : Penerbit Tarawang.

Budi Setiyono

2004 Reka Reklame: Sejarah Periklanan Indonesia 1774-1984, Jakarta : Persatuan Perusahaan Periklanan Indonesia dan Galangpress. 
Didit Widiatmoko Suwardikun

2009, The Indonesian Characters Visualization on Advertisements, Bandung : Proceeding International Conference on Art \& Design, ITB.

Didit Widiatmoko Suwardikun

2012, Karakter Visual Iklan Cetak Tahun 1950an Di Indonesia, Disertasi Program Doktor. Bandung : Institut Teknologi Bandung.

Dullah

1956 Lukisan-lukisan koleksi Ir.Dr. Sukarno, Peking, Republik Rakjat Tiongkok, Pustaka Kesenian Rakjat Peking,

Hall \& Lindzey

1993 Teori-Teori Psikodinamik, Yogyakarta, Penerbit Kanisius

Haryoto Kunto

1986 Semerbak Bunga di Bandung Raya, Bandung, Penerbit PT Granesia.

Lemaire, A.

1977 Jacques Lacan, London, Routledge \& Kegan Paul, Ltd.
Merril, F.E., Eldredge, H.W.

1956 Culture and Society, Englewood Cliffs-New Jersey : Prentice Hall, Inc.

Riclef, H.C.,

1991 Sejarah Indonesia Moderen, Yogyakarta : Gajah Mada University Press

Rose, Gillian,

2001 Visual Methodologies, An Introduction to the Interpretation of visual Materials, London: Sage Publication.

Sudarsono Katam \& Lulus Abadi

2006 Album Bandoeng Tempo Doeloe, Bandung, Nav Press Indonesia.

Wertheim, W.F.

1956 Indonesian Society In Transition A Study Of Social Change, Bandung : Penerbit Sumurbandung. 